\title{
Association Between Ambient Fine Particulate Matter and Maternal Vitamin D Levels During The Second Trimester of Pregnancy
}

\section{Chong Li}

Affiliated Kunshan Hospital of Jiangsu University

\section{Ya-qin Gong}

Affiliated Kunshan Hospital of Jiangsu University

\section{Yun-yu Xia}

Meteorological Bureau of Kunshan City

\section{Xiao-chun Wang}

Meteorological Bureau of Kunshan City

\section{Lin Chen}

Ecology and Environment Bureau of Kunshan City

\section{Shan-jun Yan}

Ecology and Environment Bureau of Kunshan City

Ke Lu ( $\nabla$ sgu8434@sina.com )

Affiliated Kunshan Hospital of Jiangsu University

\section{Research Article}

Keywords: Vitamin D, Air Pollution, Particulate Matter, Pregnancy, Meteorology

Posted Date: February 14th, 2022

DOI: https://doi.org/10.21203/rs.3.rs-1342874/v1

License: (c) (i) This work is licensed under a Creative Commons Attribution 4.0 International License. Read Full License 


\section{Abstract}

Background: Evidence for an association between the amount of ambient fine particulate matter (PM) in the atmosphere and vitamin D status of pregnant women is limited. We aimed to examine the independent association between ambient fine PM and maternal levels of serum 25-hydroxyvitamin D (250HD) during the second trimester and to explore possible modifications to the association by meteorological factors.

Methods: 27,768 pregnant women presenting for prenatal examination who were tested for serum 250HD concentration during the second trimester between January 1, 2016, and 31 December, 2020, were included in this retrospective analysis. Exposure to PM was evaluated based on daily average PM with an aerodynamic diameter of $\leq 2.5 \mu \mathrm{m}\left(\mathrm{PM}_{2.5}\right)$ and $\mathrm{PM}$ with an aerodynamic diameter of $\leq 10 \mu \mathrm{m}\left(\mathrm{PM}_{10}\right)$. Corresponding meteorological data for daily average atmospheric temperature, atmospheric pressure, relative humidity, sunshine duration, and wind speed, were collected.

Results: Vitamin D deficiency $(<12 \mathrm{ng} / \mathrm{mL})$, inadequacy $(12-20 \mathrm{ng} / \mathrm{mL})$, and adequacy $(\geq 20 \mathrm{ng} / \mathrm{mL})$ were respectively present in $23.5 \%, 41.3 \%$, and $35.2 \%$ of pregnant women during their second trimester. The maximum cumulative effects of $\mathrm{PM}_{2.5}$ occurred at lag 45 days, and the maximum cumulative effects of $\mathrm{PM}_{10}$ occurred at lag 60 days. In crude models, 45-day moving daily average $\mathrm{PM}_{2.5}$ concentrations were negatively associated with $250 \mathrm{HD}$ levels $(\beta,-0.200 ; 95 \% \mathrm{Cl},-0.206$ to -0.193$)$, as were 60 -day moving daily average $\mathrm{PM}_{10}$ concentrations $(\beta,-0.142 ; 95 \% \mathrm{Cl},-0.146$ to -0.137$)$. After adjusting for temporal and meteorological factors, the effect values were drastically reduced (adjusted $\beta$ of $\mathrm{PM}_{2.5},-0.032 ; 95 \% \mathrm{Cl}$, -0.046 to -0.018 ; adjusted $\beta$ of $\mathrm{PM}_{10},-0.039 ; 95 \% \mathrm{Cl},-0.049$ to -0.028 ).

Conclusions: Our study showed an independent negative association between ambient fine PM in the atmosphere and maternal serum $250 \mathrm{HD}$ levels during the second trimester of pregnancy. However, the effect values were small after adjusting for temporal and/or meteorological factors, which indicates that ambient fine PM may have a limited influence on maternal serum 250HD levels.

\section{Introduction}

The key fat-soluble nutrient vitamin D has multiple functions, and its deficiency is thought to be a risk factor in skeletal health and various non-skeletal conditions, such as schizophrenia, skin disorders, certain types of cancer, type 2 diabetes, and infections [1]. For pregnant women, sufficient vitamin D stores need to be maintained to provide for both themselves and their fetus [2]. Research continues to provide evidence of an association between maternal Vitamin D deficiency (VDD) and a higher risk of numerous undesirable pregnancy outcomes, such as a low body weight, respiratory tract infections, and neurocognitive developmental problems in newborns and preeclampsia and high blood pressure in mothers [3-8]. Therefore, VDD is a key clinical issue for pregnant women and deserves research attention. Throughout the world at present, VDD during pregnancy is still a frequent occurrence. In one study of pregnant women in Finland, 77.4\% were found to suffer from VDD during their first trimester [9]. While in, 
the USA, Ginde et al. [10] reported $46 \%, 32 \%$, and $18 \%$ of women with VDD in the first, second, and third trimesters, respectively, and there were comparable observations among British [11], Indian [12], and Chinese [13] women.

For the most part, factors determining the vitamin $D$ status during pregnancy do not differ from those important for the general population, such as the number of melanocytes in the skin, the amount of exposure of the skin to the sun, the amount of adipose tissue in the body, geographical latitude, dietary factors, and intake of supplementary vitamins [14-18]. An indoor lifestyle can also increase the risk of developing a VDD [19]. Moreover, the amount of PM in the atmosphere has been associated with circulating levels of 25-hydroxyvitamin D (250HD), which is a key marker for vitamin D status, in humans [20-23], including pregnant women [24].

It is not yet clear what mechanisms coordinate the links between maternal vitamin $D$ and air pollution levels. Because vitamin $D$ is a relatively scarce resource in food, humans generally rely on the vitamin $D$ produced by cells in the skin on exposure to natural solar ultraviolet (UV) B radiation $[25,26]$. Some scholars have hypothesized that the reduction in the amount of solar UVB radiation reaching ground level by ambient fine particulate matter (PM) is the main mechanism linking PM to circulating 250HD levels in humans $[23,24]$. In an investigation into the relationship between certain pollutants and ground-level UVB intensity, PM with an aerodynamic diameter of $\leq 10 \mu \mathrm{m}\left(\mathrm{PM}_{10}\right)$ was shown to be a significant negative predictor of solar UVB radiation, but the impact of $\mathrm{PM}_{10}$ was very small [27]. In addition, vitamin $\mathrm{D}$ status correlated with temporal and meteorological factors. During their second trimester, the 250HD levels of women in eastern China demonstrated variation with season and air temperature [28]. Another study reported 250HD levels were positively correlated with the prior month's temperature [29]. Thus, when exploring the independent association between ambient fine PM and vitamin D status, meteorological factors may need to be taken into account.

Thus, our study objective was to examine the independent association between ambient fine PM and maternal serum $250 \mathrm{HD}$ levels during the second trimester in pregnant women and to explore if meteorological factors have an impact on this association.

\section{Methods}

\subsection{Study Population}

We designed a single-hospital-based cross-sectional retrospective observational study to test our hypotheses. All prenatal examination data were collected from the hospital medical database in Affiliated Kunshan Hospital of Jiangsu University located in Kunshan, eastern China, at $31.2^{\circ} \mathrm{N}$ latitude and approximately 30 kilometers from Shanghai. This is the largest hospital that provides prenatal care in all the districts of Kunshan. Consecutively, 35,476 pregnant women at the 15-20th week gestation (during the second trimester) who visited our institution for prenatal examination and were tested for serum $250 H D$ concentrations between January 1, 2016, and 31 December, 2020, were included in this study. We 
excluded 7,708 women for the following reasons: those (1) with a chronic metabolic disease with consequences for the metabolism of vitamin $D(n=5,389)$; (2) with a high-risk pregnancy $(n=1,087)$, or (3) who had lived in Kunshan for less than 1 year $(n=1,232)$. Finally, 27,768 pregnant women were included in this analysis (Additional file 1: Figure S1).

The study protocol, submitted for review by the ethical committee at the Affiliated Kunshan Hospital of Jiangsu University (approval No. 2020-03-046-K01), was approved, and it complied with the Declaration of Helsinki. Patient information was initially documented for hospital's quality improvement purposes. Data analyzers were blinded to the identity of patients. Written informed consent was not required due to the anonymous data gathering and observational nature of the study.

\subsection{Measurement of Vitamin D}

In humans, the most abundant form of vitamin D in the blood is $250 \mathrm{HD}$, and serum levels are used to reliably estimate a patient's vitamin D status. All pregnant women in this study were in their 15-20th week of gestation (during the second trimester of pregnancy) and were asked to fast before blood samples were taken. Serum 250HD concentrations were measured immediately using an automated electrochemiluminescence immunoassay on a Roche Cobas 8000/e602 analyzer (Roche Diagnostics, Mannheim, Germany). There is no medical consensus regarding the status cut-off values of 25OHD concentrations. However, the Institute of Medicine (National Academy of Sciences, Washington, DC, USA) and the National Osteoporosis Society (Bath, England) concur that, for bone health, a serum 250HD level $(2.5 \mathrm{nmol} / \mathrm{L} 25 \mathrm{OHD}=1 \mathrm{ng} / \mathrm{mL} 25 \mathrm{OHD})$ of $<30 \mathrm{nmol} / \mathrm{L}(12 \mathrm{ng} / \mathrm{mL})$ is deficient, $30-50 \mathrm{nmol} / \mathrm{l}(12-20$ $\mathrm{ng} / \mathrm{mL})$ is insufficient for certain individuals, while $>50 \mathrm{nmol} / \mathrm{L}(20 \mathrm{ng} / \mathrm{mL})$ is sufficient for most people [30,31]. The time of blood collection was included in the analysis. Seasons were defined as: Spring, March-May; Summer, June-August; Autumn, September-November; Winter, DecemberFebruary.

\subsection{PM Exposure and Meteorological Data Assessment}

We received data for the daily average concentration of PM with an aerodynamic diameter of $\leq 2.5 \mu \mathrm{m}$ $\left(\mathrm{PM}_{2.5} ; \mu \mathrm{g} / \mathrm{m}^{3}\right)$ and $\mathrm{PM}_{10}\left(\mu \mathrm{g} / \mathrm{m}^{3}\right)$ from the Meteorological Bureau of Kunshan City. Meteorological data (daily average atmospheric temperature $\left[{ }^{\circ} \mathrm{C}\right]$, atmospheric pressure [hPa], relative humidity [\%], sunshine duration [hour], and wind speed [m/s]) were obtained from the Ecology and Environment Bureau of Kunshan City. The distances between the environmental and meteorological monitoring sites and the hospital are approximately 8 and 3 kilometers, respectively. Kunshan City covers an area of 927.7 square kilometers; this distance is shorter than that used for sensitivity analysis in the study by Di et al. in 2017 [32].

Because the serum 25OHD half-life is about 15 days [33], the cumulative effects of $\mathrm{PM}_{2.5}$ and $\mathrm{PM}_{10}$ on maternal serum $250 \mathrm{HD}$ levels during the second trimester of pregnancy were approximated using the moving-average lag structures (blood collection day [day 0] was not included) as follows: 0-3 days (3-day moving daily average PM concentration), 0-7 days (7-day moving daily average PM concentration), 0-15 
days (15-day moving daily average PM concentration), 0-30 days (30-day moving daily average PM concentration), 0-45 days (45-day moving daily average PM concentration), 0-60 days (60-day moving daily average PM concentration), 0-75 days (75-day moving daily average PM concentration), and $0-90$ days (90-day moving daily average PM concentration). When adjusting for the influence of meteorological factors, the corresponding moving average lag structures for the meteorological factors were calculated.

\subsection{Statistics}

The summary statistics for the characteristics of pregnant women were expressed as frequencies (proportions) for categorical variables and as the means (standard deviation [SD]) or medians (Q1-Q3) for continuous variables. We also conducted univariate logistic regression analysis to evaluate the association between the characteristics of pregnant women and maternal serum $250 \mathrm{HD}$ concentrations during the second trimester. The daily average meteorological variables and daily average $\mathrm{PM}_{2.5}, \mathrm{PM}_{10}$, and 250HD concentrations were screened for correlations by Pearson's.

Using generalized estimating equations (GEE), we evaluated the relationships between the cumulative effects of PM on maternal serum 250HD levels. The cumulative effects of PM were divided into four levels on the basis of quartiles. After adjusting for year and age at blood collection (adjust I) or year, season, and age at blood collection (adjust II), $\beta$-values (95\% confidence interval [CI]) of the maternal serum $250 \mathrm{HD}$ levels were calculated based on group trends. As part of the sensitivity analysis, we also calculated the $\beta$-values $(95 \% \mathrm{Cl})$ for the $250 \mathrm{HD}$ levels when using the concentrations of $\mathrm{PM}_{2.5}$ and $\mathrm{PM}_{10}$ as continuous variables.

Controlling for the influence of meteorological covariances by applying multivariate linear regression analysis allowed us to evaluate independent associations between the maximum cumulative effects of PM and maternal serum 250HD. We calculated the results of the unadjusted or minimally adjusted analysis and those from fully adjusted analysis. First, collinearity diagnosis of covariances was performed using variance inflation factor (VIF) analysis (the variable average atmospheric temperature was first removed due to VIF >10). Then, a judgement on whether to adjust covariances was made using the following principles: Criteria 1, the covariate is added to the basic model or removed from the full model and the matched odds ratio (OR) is changed by at least 10\%; Criteria 2: Criteria 1 or a covariate $P$ value of $<0.1$ in the univariate model [34]. As part of the sensitivity analysis, we transformed $250 \mathrm{HD}$ quantitative variables into dichotomous qualitative variables $(1=$ vitamin $D$ deficiency and inadequacy $[<20 \mathrm{ng} / \mathrm{mL}] ; 0=$ adequacy $[\geq 20 \mathrm{ng} / \mathrm{mL}])$, then the $\mathrm{OR}$ and $95 \% \mathrm{Cl}$ for maternal vitamin $D$ deficiency and inadequacy ( $<20 \mathrm{ng} / \mathrm{mL}$ ) associated with a $10 \mathrm{mg} / \mathrm{m}^{3}$ increase in $\mathrm{PM}_{2.5}$ or $\mathrm{PM}_{10}$ was determined.

Non-linear relationships were additionally identified via a generalized additive model (GAM), and on finding a non-linear correlation, the threshold effect in terms of the smoothing curve was calculated using a two-piecewise linear regression model. When a clear ratio was apparent in the smoothing curve, the recursive method was applied to automatically calculate the turning point at which to use the maximum 
likelihood model [35]. In addition, to test the robustness and potential variation in the different subgroups, we repeated the subgroup analyses while stratifying by season, age, and meteorological factors. The age threshold was derived from the turning point calculated by the GAM followed by an inspection of the modification and interaction of the subgroups with the likelihood ratio test.

All statistical analyses were performed using the Empower Stats (www.empowerstats.com, X\&Y solutions, Inc., Boston, MA, USA) and R software version 3.6.3 (http://www.r-project.org). A $P$-value $<0.05$ was set as the significance threshold.

\section{Results}

Table 1 displays the data on the pregnant women and their vitamin $\mathrm{D}$ statuses. This analysis included 27,768 individuals with a mean age of 28.86 (SD, 4.27) years. The mean (SD) and median (Q1-Q3) values of maternal serum $250 \mathrm{HD}$ concentrations during the second trimester of pregnancy were 17.7 (7.9) $\mathrm{ng} / \mathrm{mL}$ and 16.0 (12.0-22.0) ng/mL, respectively. Vitamin D deficiency, inadequacy, and adequacy were present in $23.5 \%, 41.3 \%$, and $35.2 \%$ of women, respectively. Univariate logistic regression analysis revealed that maternal $250 \mathrm{HD}$ concentration was positively associated with maternal age and showed seasonal variation, with the peak in September and the nadir in February.

Pearson's correlation analysis was conducted to compare serum 250HD concentration, meteorological variables, and air pollutant exposure. Figure S2 (Additional file 1) presents that, except $\mathrm{PM}_{2.5}$ vs. sunshine duration ( $P$-value $=0.821)$, all correlations among the variables were statistically significant $(P$-value < 0.001). There was a strong positive correlation between the daily average $\mathrm{PM}_{2.5}$ concentration and $\mathrm{PM}_{10}$ concentration, and the Pearson coefficient was 0.924 . There was also a strong negative correlation between daily average atmospheric temperature and atmospheric pressure, and the Pearson coefficient was -0.892 . There was a moderate negative correlation between daily sunshine duration and relative humidity, and the correlation coefficient was -0.683 .

Figure 1 shows periodic changes in the above indicators in terms of monthly average values over time. It can be seen that the variation in the average temperature of the last month was most consistent with the periodic variation of monthly average serum $250 H D$ concentrations. Similar periodic changes were seen for sunshine duration and relative humidity. However, monthly average $\mathrm{PM}_{2.5}$ and $\mathrm{PM}_{10}$ concentrations and atmospheric pressure showed periodic changes that were diametrically opposite to those of the monthly average serum $250 \mathrm{HD}$ concentration.

Figure 2 and Table S1 (Additional file 1) show the cumulative effects of $\mathrm{PM}_{2.5}$ and $\mathrm{PM}_{10}$ on maternal serum $250 \mathrm{HD}$ levels during the second trimester of pregnancy. After we adjusted for year, season, and age at blood collection, the maximum cumulative effects occurred at lag 0-45 days of $\mathrm{PM}_{2.5}$ and lag 0-60 days of $\mathrm{PM}_{10}$. When PM concentrations were used as continues variables, similar results were observed, and these are provided in Table S2 (Additional file 1). 
The independent associations between the maximum cumulative effects of PM and serum 250HD levels were further investigated, and Table 2 shows the results adjusted for different covariances. In the crude models, the effect sizes of $\mathrm{PM}_{2.5}(\beta,-0.200 ; 95 \% \mathrm{Cl}:-0.206$ to $-0.193 ; P$-value $<0.00001)$ and $\mathrm{PM}_{10}$ $(\beta,-0.142 ; 95 \% \mathrm{Cl}:-0.146$ to $-0.137 ; P$-value $<0.00001)$ were relatively high. After adjustments for year, season, and age at blood collection (Model 1$)$, the effect sizes of $\mathrm{PM}_{2.5}(\beta,-0.113 ; 95 \% \mathrm{Cl}:-0.125$ to -0.101; $P$-value $<0.00001)$ and $\mathrm{PM}_{10}(\beta,-0.090 ; 95 \% \mathrm{Cl}$ : -0.099 to $-0.081 ; P$-value $<0.00001)$ were reduced. On the basis of the Model 1 adjustment, the effect values of $\mathrm{PM}_{2.5}(\beta,-0.042 ; 95 \% \mathrm{Cl}:-0.055$ to -0.028; $P$-value $<0.00001)$ and $\mathrm{PM}_{10}(\beta,-0.039 ; 95 \% \mathrm{Cl}$ : -0.049 to $-0.030 ; P$-value $<0.00001)$ were further reduced after adding atmospheric pressure adjustment (Model 2). After further adjustment for sunshine duration, the effect values of Model 3 were similar to those of Model 2. In the fully adjusted Model 4 (adjusted for year, age, season, daily average atmospheric pressure, sunshine duration, relative humidity, and wind speed), there was a negative relationship between the 45-day moving daily average $\mathrm{PM}_{2.5}$ concentration and the women's $250 \mathrm{HD}$ levels $(\beta,-0.032 ; 95 \% \mathrm{Cl},-0.046$ to $-0.018 ; P$-value $<0.00001)$, and the 60-day moving daily average $\mathrm{PM}_{10}$ concentration was negatively associated with $250 \mathrm{HD}$ levels $(\beta,-0.039 ; 95 \% \mathrm{Cl},-0.049$ to $-0.028 ; P$-value $<0.00001)$. As part of the sensitivity analysis, the crude and adjusted OR for PM exposure's association with maternal vitamin D deficiency and inadequacy $(<20$ $\mathrm{ng} / \mathrm{mL}$ ) were determined, which are given in Table S3 (Additional file 1). We observed greater odds of maternal vitamin D deficiency and inadequacy $(<20 \mathrm{ng} / \mathrm{mL})$ with higher PM levels. In the fully adjusted Model 4, an increase in the $\mathrm{PM}_{2.5}$ 45-day moving daily average by $10 \mathrm{mg} / \mathrm{m}^{3}$ was associated with a $12.4 \%(\mathrm{OR}, 1.124 ; 95 \% \mathrm{Cl}, 1.071$ to $1.180, P$-value $<0.00001)$ increase in the odds for maternal vitamin $\mathrm{D}$ deficiency and inadequacy ( $<20 \mathrm{ng} / \mathrm{mL}$ ). In the fully adjusted Model 4 , a $10 \mathrm{mg} / \mathrm{m}^{3}$ increase in the $\mathrm{PM}_{10}$ 60 -day moving daily average was associated with a $11.3 \%(\mathrm{OR}, 1.113 ; 95 \% \mathrm{Cl}, 1.074$ to $1.153, P$ value $<0.00001)$ increase in the odds of maternal vitamin $D$ deficiency and inadequacy $(<20 \mathrm{ng} / \mathrm{mL})$.

In the subgroup analyses stratified by season, we further investigated the role of season on the association between the maximum cumulative effects of PM and serum $250 \mathrm{HD}$ levels. For $\mathrm{PM}_{2.5}(\mathrm{Table}$ $3)$, both linear and nonlinear effect values were higher in summer and autumn and lower in winter and spring ( $P$-values for interaction $<0.001)$. Figure $3 \mathrm{~A}$ shows the different nonlinear associations between the 45-day moving daily average $\mathrm{PM}_{2.5}$ concentration and maternal serum $250 \mathrm{HD}$ levels stratified by season. In addition, we calculated, using the two-piecewise linear regression model, the turning point of the adjusted smoothed curve. Specifically, the difference between the two slopes was at its maximum in autumn, and the turning point (45-day moving daily average $\mathrm{PM}_{2.5}$ concentration) was $31.11 \mu \mathrm{g} / \mathrm{m}^{3}$. For $\mathrm{PM}_{10}$ (Table 3), linear regression analysis showed a significant interaction for season (interaction $P$-value $<0.001$ ), but the non-linear model showed this interaction was not significant (interaction $P$-value $=$ 0.383). Figure 3B shows the different nonlinear associations between the 60-day moving daily average $\mathrm{PM}_{10}$ concentration and maternal serum $250 \mathrm{HD}$ levels stratified by season. It is worth mentioning that, in autumn, the relationship between $\mathrm{PM}_{10}$ and $250 \mathrm{HD}$ levels was nonlinear, and the turning point was 38.10 $\mu \mathrm{g} / \mathrm{m}^{3}$. Specifically, when the 60 -day moving daily average $\mathrm{PM}_{10}$ concentration ranged from $32.32 \mu \mathrm{g} / \mathrm{m}^{3}$ 
to $38.10 \mu \mathrm{g} / \mathrm{m}^{3}$, a stronger negative relationship was found between $\mathrm{PM}_{10}$ and serum $250 \mathrm{HD}$ levels ( $\beta$, $-1.121 ; 95 \% \mathrm{Cl},-1.513$ to -0.728 ; $P$-value $<0.0001$; number of pregnant women, 878 ).

The threshold effect analysis used to examine the associations between maternal age and serum 250HD levels during the second trimester of pregnancy revealed a stronger positive relationship between age and serum 250HD levels when the women were 15 to 25 years of age and a weaker positive relationship when they were 25 to 47 . The results of four different adjusted models were robust (Additional file 1: Figure S3 and Table S4). We then categorized the pregnant women using a threshold of 25 years according to the results of the threshold effect analysis and further investigated the modification effect of age on the association between the maximum cumulative effects of PM and serum 250HD levels. Table S5 (Additional file 1)shows that the interaction between age and $\mathrm{PM}_{2.5}$ was not significant (linear interaction $P$-value $=0.083$ and non-linear interaction $P$-value $=0.058$ ), while Table S6 (Additional file 1) shows the interaction between age and $\mathrm{PM}_{10}$ had a marginally significant effect on serum $250 \mathrm{HD}$ levels (linear $P$-value for interaction $=0.045$ and non-linear $P$-value for interaction $=0.038$ ).

In the subgroup analyses stratified by meteorological factors, Table 4 showed the associations between $\mathrm{PM}$ and serum $250 \mathrm{HD}$ levels during the second trimester of pregnancy were generally modified by meteorological factors, although wind speed had no modification effect on $\mathrm{PM}_{2.5}$. Of particular interest, there was a positive association between PM concentration and 250HD levels under low relative humidity. The result of this stratification was the opposite to the final conclusion.

\section{Discussion}

Based on our knowledge of the literature, this epidemiological study is the first to focus on the independent relationship between PM and maternal serum 250HD levels during the second trimester of pregnancy after adjusting for meteorological factors. We found vitamin D deficiency, inadequacy, and adequacy in $23.5 \%, 41.3 \%$, and $35.2 \%$ of pregnant women during the second trimester of pregnancy, respectively. Prenatal exposure to higher levels of PM was associated with decreased maternal serum $250 \mathrm{HD}$ concentrations. We also found that the maximum cumulative effects of $\mathrm{PM}_{2.5}$ occurred at lag 45 days and the maximum cumulative effects of $\mathrm{PM}_{10}$ occurred at lag 60 days. However, the effect values were drastically reduced after adjusting for temporal and/or meteorological factors. The results indicated that ambient fine PM has a limited influence on maternal serum 250HD levels.

Our conclusions are similar to those of Zhao et al., who reported an association between prenatal exposure to higher $\mathrm{PM}_{2.5}$ and $\mathrm{PM}_{10}$ levels and a decrease in circulating 250HD concentrations in women in later stages of pregnancy [24]. In contrast to the analysis they conducted, we first investigated the time window for the largest cumulative effect of PM at the individual level and then adjusted for temporal and meteorological factors. Although both effect sizes of $\mathrm{PM}_{2.5}$ and $\mathrm{PM}_{10}$ in the fully adjusted models were small ( $\beta$-value of $\mathrm{PM}_{2.5}=-0.032 ; \beta$-value of $\mathrm{PM}_{10}=-0.039$, respectively), they were highly significant $(P$ value $<0.00001)$. The $\beta$-values showed two large drops, one after adjusting for season and the other after 
adjusting for atmospheric pressure. Due to the collinearity of atmospheric pressure and temperature, it can be inferred that season and atmospheric pressure/temperature may have been important confounders in the regression model. Thus, in some correlation analyses of PM and vitamin D levels, the independent role of PM may have been overestimated when there was no adjustment for meteorological factors.

Indeed, in areas with distinct seasons, $250 \mathrm{HD}$ concentrations in the population fluctuate over time $[29,36$, 37]. Many studies showed season to be the primary factor affecting serum $250 H D$ levels $[15,29,38-40]$. Periodic changes in the seasons affect periodic changes in meteorological factors, such as temperature, humidity, and sunshine duration. Hence, unlike other studies that only adjusted for season, our study precisely adjusted for meteorological factor exposure at the individual level.

On the other hand, meteorological factors are also related to periodic changes in PM concentrations. Weather and climate are the most influential forces affecting the chemistry and atmospheric residence time of PM [41]. In a study in China, the geographical and temporal variations in PM levels and coinciding meteorological conditions were analyzed for 366 cities, and peak PM concentrations occurred in winter in most regions, and there were negative correlations between PM levels and precipitation, relative humidity, air temperature, and wind speed but a positively correlation was found between PM levels and surface pressure [42]. Guan et al. [43] reported the spatiotemporal variability of PM in three cities in western China and the influence of meteorological factors on PM. Crawford et al. [44], who analyzed the impact of meteorology on particulate source types in Lucas Heights, Australia, reported that temperature significantly affected $\mathrm{PM}_{2.5}$ levels. An Indian study reported that PM displayed substantial seasonal variations and a strong negative association with temperature, with considerable dependency levels [41].

Over $90 \%$ of the vitamin D in the body is synthesized in human skin after the exposer of precursor 7dehydrocholesterol to UVB (290-315 $\mathrm{nm})$ radiation from the sun [45]. The strength of the UVB during sun exposure, and therefore the amount of vitamin $D$ synthesized, is affected by solar zenith angle (SZA) -the angle between the local vertical and the sun's position. Hence, the most intense solar radiation occurs when the SZA is small, i.e., which at lower altitudes, is around 11:00-15:00h in the summer, at which time the synthesis of vitamin $D$ by the skin is most active [46]. At latitudes $>50^{\circ}$, human skin participates in very little vitamin D synthesis during winter and spring for all skin types and ethnicities [47]. In addition, the amount of vitamin D produced is dependent on local weather conditions, such as the percentage cloud cover, which filters UVB radiation, and has an impact in all seasons and hours of the day [37]. Thus, because PM can absorb and diffuse solar irradiation, some scholars have hypothesized that PM can indirectly reduce vitamin $D$ formation by reducing UVB exposure $[23,24]$. However, other scholars have argued that there is significant spatiotemporal variation in the morphology, chemical makeup, density of $\mathrm{PM}$, and it is difficult to determine its effect on UV radiation [48]. More recently, $\mathrm{PM}_{10}$ was found to be a significant negative predictor of solar UVB radiation, but the effect of $\mathrm{PM}_{10}$ was miniscule [27]. This conclusion can be used to further deduce that $\mathrm{PM}_{10}$ has an effect on vitamin $\mathrm{D}$ levels, but the effect is small, which is consist with the results of our study. Combined with the above views, we propose a hypothesis (see Additional file 1: Figure S4) that PM and meteorological factors indirectly influence the 
cyclical changes of vitamin $D$ in pregnant women by impacting the level of personal UVB exposure. For example, in winter, when the temperature is lower and there are fewer hours of sunshine, the PM concentration is higher, but pregnant women spend less time outdoors and wear more clothes, which lead to lower solar UVB radiation exposure, reducing the synthesis of vitamin D.

In the subgroup analysis, with the exception of the low relative humidity, a negative effect between PM and $250 H D$ was evident in all subgroups considered and after careful adjustments. In the interaction analysis, season and most meteorological factors interacted with the association between PM and 250HD. However, the mechanisms of their interactions were unclear and need to be further investigated in the future.

There were some limitations regarding our study. First, our results were obtained from a Chinese population of pregnant women during the second trimester and cannot be extrapolated to other populations. Second, the study was an analytical retrospective study and hence provides limited evidence that PM exposure and vitamin D outcomes were related, and the difference between cause and effect is uncertain. Third, demographic information was lacking (education level, vitamin D/calcium supplement use, outdoor activities, use of sun protection, and BMI, etc.) for the individuals whose test results were used. However, valuable insights can be gleaned from the study, as it involved the retrospective analysis of a large dataset from a prenatal examination population. We used precise adjustments at the individual level to reveal whether PM levels are independently associated with 250HD concentration.

\section{Conclusion}

Our study revealed an independent negative association between ambient fine PM and maternal serum $250 \mathrm{HD}$ levels during the second trimester of pregnancy. However, the effect values were drastically reduced after adjusting for temporal and/or meteorological factors, which indicates that ambient fine PM may have a limited influence on maternal serum 250HD levels.

\section{Declarations}

\section{Funding}

This study was funded by National Natural Science Foundation of China (CN) [82172441], Clinical Medical Science and Technology Development Fund of Jiangsu University (CN) (JLY2021048) and Suzhou Key Clinical Diagnosis and Treatment Technology Project (CN) (LCZX202024).

\section{Competing interests}

The authors declare that they have no competing interests.

\section{Ethics approval}


This study complies with the Declaration of Helsinki and has been approved by the Ethics Committee of the First People's Hospital of Kunshan (no. 2020-03-046-K01).

Availability of data and materials

The datasets used and/or analyzed during the current study are available from the corresponding author on reasonable request.

\section{Authors' contributions}

Ke Lu contributed to the study conception and design. Ya-qin Gong, Yun-yu Xia, Xiao-chun Wang, Lin Chen and Shan-jun Yan contributed to the acquisition of data. Ke Lu and Ya-qin Gong contributed to the analysis and interpretation of data. Chong Li drafted the manuscript, and Ke Lu revised it. All authors critically revised the manuscript, agree to be fully accountable for ensuring the integrity and accuracy of the work, and read and approved the final manuscript.

\section{Acknowledgements}

Not applicable

\section{References}

1. Holick MF: Vitamin D: evolutionary, physiological and health perspectives. Curr Drug Targets 2011, 12(1):4-18.

2. Hatun S, Ozkan B, Orbak Z, Doneray H, Cizmecioglu F, Toprak D, Calikoglu AS: Vitamin D deficiency in early infancy. J Nutr 2005, 135(2):279-282.

3. Achkar M, Dodds L, Giguère Y, Forest JC, Armson BA, Woolcott C, Agellon S, Spencer A, Weiler HA: Vitamin D status in early pregnancy and risk of preeclampsia. Am J Obstet Gyneco/2015, 212(4):511.e511-517.

4. Arnold DL, Enquobahrie DA, Qiu C, Huang J, Grote N, VanderStoep A, Williams MA: Early pregnancy maternal vitamin $\mathrm{D}$ concentrations and risk of gestational diabetes mellitus. Paediatr Perinat Epidemiol 2015, 29(3):200-210.

5. Wang H, Xiao Y, Zhang L, Gao Q: Maternal early pregnancy vitamin D status in relation to low birth weight and small-for-gestational-age offspring. J Steroid Biochem Mol Biol 2018, 175:146-150.

6. Murthi P, Davies-Tuck M, Lappas M, Singh H, Mockler J, Rahman R, Lim R, Leaw B, Doery J, Wallace EM et al: Maternal 25-hydroxyvitamin $\mathrm{D}$ is inversely correlated with foetal serotonin. Clin Endocrinol (Oxf) 2017, 86(3):401-409.

7. Meems LM, Mahmud H, Buikema H, Tost J, Michel S, Takens J, Verkaik-Schakel RN, VreeswijkBaudoin I, Mateo-Leach IV, van der Harst $\mathrm{P}$ et al: Parental vitamin D deficiency during pregnancy is associated with increased blood pressure in offspring via Panx1 hypermethylation. Am J Physiol Heart Circ Physio/ 2016, 311(6):H1459-h1469. 
8. Weinert LS, Silveiro SP: Maternal-fetal impact of vitamin D deficiency: a critical review. Matern Child Health J 2015, 19(1):94-101.

9. Viljakainen HT, Saarnio E, Hytinantti T, Miettinen M, Surcel H, Mäkitie O, Andersson S, Laitinen K, Lamberg-Allardt C: Maternal vitamin D status determines bone variables in the newborn. J Clin Endocrinol Metab 2010, 95(4):1749-1757.

10. Ginde AA, Sullivan AF, Mansbach JM, Camargo CA, Jr.: Vitamin D insufficiency in pregnant and nonpregnant women of childbearing age in the United States. Am J Obstet Gynecol 2010, 202(5):436.e431-438.

11. McAree T, Jacobs B, Manickavasagar T, Sivalokanathan S, Brennan L, Bassett P, Rainbow S, Blair M: Vitamin D deficiency in pregnancy - still a public health issue. Matern Child Nutr 2013, 9(1):23-30.

12. Vijayendra Chary A, Hemalatha R, Seshacharyulu M, Vasudeva Murali M, Jayaprakash D, Dinesh Kumar B: Vitamin D deficiency in pregnant women impairs regulatory T cell function. J Steroid Biochem Mol Biol 2015, 147:48-55.

13. Song SJ, Zhou L, Si S, Liu J, Zhou J, Feng K, Wu J, Zhang W: The high prevalence of vitamin D deficiency and its related maternal factors in pregnant women in Beijing. PloS one 2013, 8(12):e85081.

14. Bodnar LM, Catov JM, Roberts JM, Simhan HN: Prepregnancy obesity predicts poor vitamin D status in mothers and their neonates. J Nutr 2007, 137(11):2437-2442.

15. Bodnar LM, Simhan HN, Powers RW, Frank MP, Cooperstein E, Roberts JM: High prevalence of vitamin $D$ insufficiency in black and white pregnant women residing in the northern United States and their neonates. J Nutr 2007, 137(2):447-452.

16. Brembeck $P$, Winkvist $A$, Olausson H: Determinants of vitamin D status in pregnant fair-skinned women in Sweden. Br J Nutr 2013, 110(5):856-864.

17. Jensen CB, Petersen SB, Granström C, Maslova E, Mølgaard C, Olsen SF: Sources and determinants of vitamin D intake in Danish pregnant women. Nutrients 2012, 4(4):259-272.

18. Richard A, Rohrmann S, Quack Lötscher KC: Prevalence of Vitamin D Deficiency and Its Associations with Skin Color in Pregnant Women in the First Trimester in a Sample from Switzerland. Nutrients 2017, 9(3).

19. Sowah D, Fan X, Dennett L, Hagtvedt R, Straube S: Vitamin D levels and deficiency with different occupations: a systematic review. BMC Public Health 2017, 17(1):519.

20. Agarwal KS, Mughal MZ, Upadhyay P, Berry JL, Mawer EB, Puliyel JM: The impact of atmospheric pollution on vitamin D status of infants and toddlers in Delhi, India. Arch Dis Child 2002, 87(2):111113.

21. Kelishadi R, Moeini R, Poursafa P, Farajian S, Yousefy H, Okhovat-Souraki AA: Independent association between air pollutants and vitamin D deficiency in young children in Isfahan, Iran. Paediatr Int Child Health 2014, 34(1):50-55.

22. Feizabad E, Hossein-Nezhad A, Maghbooli Z, Ramezani M, Hashemian R, Moattari S: Impact of air pollution on vitamin D deficiency and bone health in adolescents. Arch Osteoporos 2017, $12(1): 34$. 
23. Yang C, Li D, Tian Y, Wang P: Ambient Air Pollutions Are Associated with Vitamin D Status. Int J Environ Res Public Health 2021, 18(13).

24. Zhao Y, Wang L, Liu H, Cao Z, Su X, Cai J, Hua J: Particulate Air Pollution Exposure and Plasma Vitamin D Levels in Pregnant Women: A Longitudinal Cohort Study. J Clin Endocrinol Metab 2019, 104(8):3320-3326.

25. Glerup H, Mikkelsen K, Poulsen L, Hass E, Overbeck S, Thomsen J, Charles P, Eriksen EF: Commonly recommended daily intake of vitamin $\mathrm{D}$ is not sufficient if sunlight exposure is limited. $J$ Intern Med 2000, 247(2):260-268.

26. Chen TC, Chimeh F, Lu Z, Mathieu J, Person KS, Zhang A, Kohn N, Martinello S, Berkowitz R, Holick MF: Factors that influence the cutaneous synthesis and dietary sources of vitamin D. Arch Biochem Biophys 2007, 460(2):213-217.

27. Rahman A, Elmi A: Air pollutants are negatively associated with vitamin D-synthesizing UVB radiation intensity on the ground. Sci Rep 2021, 11(1):21480.

28. Xiao JP, Zang J, Pei JJ, Xu F, Zhu Y, Liao XP: Low maternal vitamin D status during the second trimester of pregnancy: a cross-sectional study in Wuxi, China. PloS one 2015, 10(2):e0117748.

29. Ding F, Nie X, Li X, He Y, Li G: Data mining: Biological and temporal factors associated with blood parathyroid hormone, vitamin $\mathrm{D}$, and calcium concentrations in the Southwestern Chinese population. Clin Biochem 2021, 90:50-57.

30. Aspray TJ, Bowring C, Fraser W, Gittoes N, Javaid MK, Macdonald H, Patel S, Selby P, Tanna N, Francis RM: National Osteoporosis Society vitamin D guideline summary. Age Ageing 2014, 43(5):592-595.

31. Institute of Medicine Committee to Review Dietary Reference Intakes for Vitamin D, Calcium: The National Academies Collection: Reports funded by National Institutes of Health. In: Dietary Reference Intakes for Calcium and Vitamin D. Edited by Ross AC, Taylor CL, Yaktine AL, Del Valle HB.

Washington (DC): National Academies Press (US) Copyright @ 2011, National Academy of Sciences.; 2011.

32. Di Q, Wang Y, Zanobetti A, Wang Y, Koutrakis P, Choirat C, Dominici F, Schwartz JD: Air Pollution and Mortality in the Medicare Population. N Engl J Med 2017, 376(26):2513-2522.

33. Jones KS, Assar S, Vanderschueren D, Bouillon R, Prentice A, Schoenmakers I: Predictors of 25(OH)D half-life and plasma 25(OH)D concentration in The Gambia and the UK. Osteoporos Int 2015, 26(3):1137-1146.

34. Kernan WN, Viscoli CM, Brass LM, Broderick JP, Brott T, Feldmann E, Morgenstern LB, Wilterdink JL, Horwitz RI: Phenylpropanolamine and the risk of hemorrhagic stroke. N Engl J Med 2000, 343(25):1826-1832.

35. Liu S, Wang X, Lu Y, Li T, Gong Z, Sheng T, Hu B, Peng Z, Sun X: The effects of intraoperative cryoprecipitate transfusion on acute renal failure following orthotropic liver transplantation. Hepatol Int 2013, 7(3):901-909. 
36. Dovnik A, Mujezinović F, Treiber M, Pečovnik Balon B, Gorenjak M, Maver U, Takač I: Determinants of maternal vitamin D concentrations in Slovenia : A prospective observational study. Wien Klin Wochenschr 2017, 129(1-2):21-28.

37. Saraff V, Shaw N: Sunshine and vitamin D. Arch Dis Child 2016, 101(2):190-192.

38. Yuan Y, Liu H, Ji C, Guo X, Hu L, Wen J, Cai M: Association of Maternal Serum 25-hydroxyvitamin D Concentrations in Second Trimester with Delivery Mode in A Chinese Population. Int J Med Sci 2017, 14(10):1008-1014.

39. Krieger JP, Cabaset S, Canonica C, Christoffel L, Richard A, Schröder T, von Wattenwyl BL, Rohrmann S, Lötscher KQ: Prevalence and determinants of vitamin D deficiency in the third trimester of pregnancy: a multicentre study in Switzerland. Br J Nutr 2018, 119(3):299-309.

40. Li H, Ma J, Huang R, Wen Y, Liu G, Xuan M, Yang L, Yang J, Song L: Prevalence of vitamin D deficiency in the pregnant women: an observational study in Shanghai, China. Arch Public Health 2020, 78:31.

41. Murari V, Kumar M, Mhawish A, Barman SC, Banerjee T: Airborne particulate in Varanasi over middle Indo-Gangetic Plain: variation in particulate types and meteorological influences. Environ Monit Assess 2017, 189(4):157.

42. Li X, Song H, Zhai S, Lu S, Kong Y, Xia H, Zhao H: Particulate matter pollution in Chinese cities: Arealtemporal variations and their relationships with meteorological conditions (2015-2017). Environ Pollut 2019, 246:11-18.

43. Guan Q, Cai A, Wang F, Yang L, Xu C, Liu Z: Spatio-temporal variability of particulate matter in the key part of Gansu Province, Western China. Environ Pollut 2017, 230:189-198.

44. Chambers, Scott, Williams, Alastair, Crawford, Jagoda, Stelcer, Eduard, Dyer, Leisa: Impact of meteorology on fine aerosols at Lucas Heights, Australia. Atmospheric Environment 2016.

45. Diehl JW, Chiu MW: Effects of ambient sunlight and photoprotection on vitamin D status. Dermatol Ther 2010, 23(1):48-60.

46. Webb AR: Who, what, where and when-influences on cutaneous vitamin D synthesis. Prog Biophys $\mathrm{Mol}$ Biol 2006, 92(1):17-25.

47. Webb AR, Kline L, Holick MF: Influence of season and latitude on the cutaneous synthesis of vitamin D3: exposure to winter sunlight in Boston and Edmonton will not promote vitamin D3 synthesis in human skin. J Clin Endocrinol Metab 1988, 67(2):373-378.

48. Zegarska B, Pietkun K, Zegarski W, Bolibok P, Wiśniewski M, Roszek K, Czarnecka J, Nowacki M: Air pollution, UV irradiation and skin carcinogenesis: what we know, where we stand and what is likely to happen in the future? Postepy Dermatol Alergo/ 2017, 34(1):6-14.

\section{Tables}

Table 1. Characteristics of study participants $(N=27,768)$ 
Characteristics

Maternal serum 250HD concentrations during pregnancy continuous, Mean (SD) Median (Q1-Q3), $\mathrm{ng} / \mathrm{mL}$
Statistics

$\begin{array}{lll}\text { Mean } & (95 \% \mathrm{Cl})^{\text {a }} & \begin{array}{l}P- \\ \text { value }^{\mathrm{a}}\end{array} \\ \text { (SD) } & & \\ \mathrm{ng} / \mathrm{mL} & & \end{array}$

17.7

(7.9)

16.0

(12.0-

22.0)

Maternal serum 250HD concentrations during

pregnancy categorical, $\mathrm{N}(\%)$

Deficiency $(<12 \mathrm{ng} / \mathrm{mL})$

Inadequacy $(>=12,<20 \mathrm{ng} / \mathrm{mL})$

Adequacy ( $>=20 \mathrm{ng} / \mathrm{mL}$ )
6532

$(23.5 \%)$

11465

$(41.3 \%)$

9771

(35.2\%)

Age tertile, $\mathrm{N}(\%)$

Tertile 1 (15 - 26 y)

8605

(30.99\%)

17.18

Reference

(7.70)

Tertile $2(27-29 y)$

7948

17.57
$(7.85)$

$(28.62 \%)$

(7.85)

0.39

$(0.15$,

$0.63)$

Tertile $3(30$ - $47 \mathrm{y})$

11215

$(40.39 \%)$

18.08

(8.03)

0.90

(0.68,

1.12)

$P$ for trend

$<0.0001$

Year of blood collection, $\mathrm{N}(\%)$

2016

5943

(21.40\%)

16.28

(7.45)

2017

7410

18.10

(26.69\%)

(7.65)

1.82

(1.55,

2.08)

2018

5616

(20.22\%)

17.68

(8.52)

1.40

(1.11,

1.68)

2019

5204

(18.74\%)

18.38

(7.96)

2.10

(1.81,

2.39)

2020

3595

17.94

1.65

$<0.0001$ 


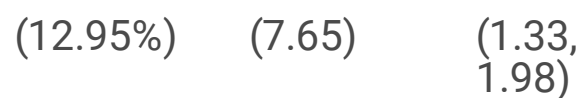

$P$ for trend

$<$

0.0001

Month of blood collection, N (\%)

January

2161

13.83

Reference -

$(7.78 \%) \quad(7.02)$

February

1549

$(5.58 \%)$

13.65

(6.69)

$-0.18$

$(-0.66$,

0.4535

$0.29)$

March

2285

$(8.23 \%)$

14.37

(6.91)

0.54

(0.11,

$0.97)$

April

2676

(9.64\%)

16.19

2.36

(1.95,

2.77)

May

2578

(9.28\%)

(7.24)

1.93

15.76

(6.80)

(1.52,

2.35)

June

2505

(9.02\%)

18.98

(7.23)

5.15

(4.73,

5.56)

July

2617

(9.42\%)

20.05

6.22

(5.81,

6.64)

August

2381

(8.57\%)

22.10

(7.97)

8.27

(7.85,

8.70)

September

2276

(8.20\%)

22.45

(8.09)

8.62

(8.19,

9.05)

October

2183

(7.86\%)

20.65

(7.78)

6.82

(6.38,

7.25)

November

2273

(8.19\%)

17.53

(7.27)

3.70

(3.27,

4.13)

December

2284

(8.23\%)

14.79

(6.74)

0.96

(0.53,

1.39)

$P$ for trend

$<$

0.0001 
Season of blood collection, N (\%)

Spring (March, April and May)

$\begin{array}{lll}7539 & 15.49 & \text { Reference - }\end{array}$

(27.15\%) (7.03)

Summer (June, July and August)

$7503 \quad 20.34$

$(27.02 \%) \quad(7.64)$

4.85

$(4.61$,

$5.09)$

Autumn (September, October and November)

6732

(24.24\%)

20.20

(7.98)

4.71

(4.47,

4.95)

Winter (December, January and February)

5994

$(21.59 \%)$

14.15

(6.85)

$-1.34$

$(-1.60$

$-1.09)$

$P$ for trend

$<$

0.0001

Abbreviations: 25OHD, 25-hydroxy vitamin D; OR, odds ratio; Cl, confidence interval; SD, standard deviation.

${ }^{a}$ Crude associations with maternal serum 25OHD concentrations during pregnancy continuous.

Table 2. Associations of the maximum cumulative effects of PM and maternal serum 250HD levels during the second trimester in models adjusted for different temporal and meteorological factors

\begin{tabular}{|c|c|c|}
\hline \multirow[t]{3}{*}{ Model } & \multicolumn{2}{|l|}{$\beta(95 \% \mathrm{Cl})$} \\
\hline & \multicolumn{2}{|l|}{$P$-value } \\
\hline & $\begin{array}{l}\text { 45-day moving daily average } \\
\mathrm{PM}_{2.5} \text { concentration }\end{array}$ & $\begin{array}{l}\text { 60-day moving daily average } \\
\mathrm{PM}_{10} \text { concentration }\end{array}$ \\
\hline Crude Model ${ }^{\mathrm{a}}$ & $\begin{array}{l}-0.200(-0.206,-0.193) \\
<0.00001\end{array}$ & $\begin{array}{l}-0.142(-0.146,-0.137) \\
<0.00001\end{array}$ \\
\hline Model 1 (Age + Year + Season $)^{b}$ & $\begin{array}{l}-0.113(-0.125,-0.101) \\
<0.00001\end{array}$ & $\begin{array}{l}-0.090(-0.099,-0.081) \\
<0.00001\end{array}$ \\
\hline $\begin{array}{l}\text { Model } 2 \text { (Model } 1+\text { Atmospheric } \\
\text { Pressure) }\end{array}$ & $\begin{array}{l}-0.042(-0.055,-0.028) \\
<0.00001\end{array}$ & $\begin{array}{l}-0.039(-0.049,-0.030) \\
<0.00001\end{array}$ \\
\hline $\begin{array}{l}\text { Model } 3 \text { (Model } 2+\text { Sunshine } \\
\text { Duration) }\end{array}$ & $\begin{array}{l}-0.039(-0.053,-0.026) \\
<0.00001\end{array}$ & $\begin{array}{l}-0.046(-0.055,-0.036) \\
<0.00001\end{array}$ \\
\hline $\begin{array}{l}\text { Model } 4 \text { (Model } 3+\text { Relative } \\
\text { Humidity +Wind Speed) }\end{array}$ & $\begin{array}{l}-0.032(-0.046,-0.018) \\
<0.00001\end{array}$ & $\begin{array}{l}-0.039(-0.049,-0.028) \\
<0.00001\end{array}$ \\
\hline
\end{tabular}

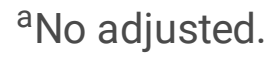

${ }^{\mathrm{b}}$ Adjusted for year, age and season. 
${ }^{c}$ Adjusted for year, age, season, and corresponding-day moving daily average atmospheric pressure.

${ }^{d}$ Adjusted for year, age, season, the corresponding-day moving daily average atmospheric pressure and sunshine duration.

${ }^{\text {e}}$ Adjusted for year, age, season, the corresponding-day moving daily average atmospheric pressure, sunshine duration, relative humidity and wind speed.

Abbreviations: $\mathrm{PM}$, particulate matter; $\mathrm{PM}_{2.5}$, particulate matter with an aerodynamic diameter of $\leq 2.5$ $\mu \mathrm{m} ; \mathrm{PM}_{10}$, particulate matter with an aerodynamic diameter of $\leq 10 \mu \mathrm{m} ; 250 \mathrm{HD}, 25$-hydroxy vitamin $\mathrm{D} ; \mathrm{Cl}$, confidence interval.

Table 3A. Threshold effect analysis examining associations between 45-day moving daily average $\mathrm{PM}_{2.5}$ levels and maternal serum 250HD levels during second trimester in subgroups stratified by season of blood collection 


\begin{tabular}{|c|c|c|c|c|c|}
\hline & Spring & Summer & Autumn & Winter & Total \\
\hline Model $A^{a}$ & & & & & $\begin{array}{l}P \text { - } \\
\text { interaction: } \\
<0.001\end{array}$ \\
\hline $\begin{array}{l}\text { One line slope, } \beta \\
(95 \% \mathrm{Cl}) P \text {-value }\end{array}$ & $\begin{array}{l}-0.027 \\
(-0.069 \\
0.014) \\
0.1919\end{array}$ & $\begin{array}{l}-0.187 \\
(-0.247 \\
-0.128) \\
<0.0001\end{array}$ & $\begin{array}{l}-0.173 \\
(-0.250 \\
-0.097) \\
<0.0001\end{array}$ & $\begin{array}{l}-0.029 \\
(-0.051 \\
-0.006) \\
0.0136\end{array}$ & $\begin{array}{l}-0.032 \\
(-0.046 \\
-0.018) \\
<0.0001\end{array}$ \\
\hline Model $B^{b}$ & & & & & $\begin{array}{l}P \text { - } \\
\text { interaction: } \\
<0.001\end{array}$ \\
\hline $\begin{array}{l}\text { Turning point }(\mathrm{K}) \text {, } \\
\mu \mathrm{g} / \mathrm{m}^{3}\end{array}$ & 38.62 & 35.4 & 31.11 & 46.31 & 20.07 \\
\hline $\begin{array}{l}\quad<\mathrm{K}, \beta(95 \% \mathrm{Cl}) P \text { - } \\
\text { value }\end{array}$ & $\begin{array}{l}-0.229 \\
(-0.331 \\
-0.127) \\
<0.0001\end{array}$ & $\begin{array}{l}-0.348 \\
(-0.427 \\
-0.268) \\
<0.0001\end{array}$ & $\begin{array}{l}0.020 \\
(-0.086, \\
0.125) \\
0.7130\end{array}$ & $\begin{array}{l}-0.130 \\
(-0.192 \\
-0.068) \\
<0.0001\end{array}$ & $\begin{array}{l}-1.798 \\
(-2.065 \\
-1.532) \\
<0.0001\end{array}$ \\
\hline $\begin{array}{l}>\mathrm{K}, \beta(95 \% \mathrm{Cl}) P \text { - } \\
\text { value }\end{array}$ & $\begin{array}{l}0.080 \\
(0.016, \\
0.145) \\
0.0150\end{array}$ & $\begin{array}{l}0.169 \\
(0.038, \\
0.300) \\
0.0115\end{array}$ & $\begin{array}{l}-0.552 \\
(-0.713 \\
-0.390) \\
<0.0001\end{array}$ & $\begin{array}{l}-0.013 \\
(-0.038 \\
0.011) \\
0.2825\end{array}$ & $\begin{array}{l}-0.022 \\
(-0.036 \\
-0.008) \\
0.0018\end{array}$ \\
\hline $\begin{array}{c}\text { Slope } 2 \text { - Slope } \\
\text { 1, } \beta(95 \% \mathrm{Cl}) P \text {-value }\end{array}$ & $\begin{array}{l}0.309 \\
(0.166 \\
0.452) \\
<0.0001\end{array}$ & $\begin{array}{l}0.516 \\
(0.347 \\
0.685) \\
<0.0001\end{array}$ & $\begin{array}{l}-0.571 \\
(-0.787 \\
-0.356) \\
<0.0001\end{array}$ & $\begin{array}{l}0.117 \\
(0.050, \\
0.183) \\
0.0006\end{array}$ & $\begin{array}{l}1.776 \\
(1.509 \\
2.044) \\
<0.0001\end{array}$ \\
\hline $\begin{array}{l}\text { Predicted } 250 \mathrm{HD} \\
\text { levels at K }(95 \% \mathrm{Cl}) \\
\mathrm{ng} / \mathrm{mL}\end{array}$ & $\begin{array}{l}15.977 \\
(15.655 \\
16.298)\end{array}$ & $\begin{array}{l}18.303 \\
(17.982 \\
18.625)\end{array}$ & $\begin{array}{l}19.469 \\
(19.137 \\
19.802)\end{array}$ & $\begin{array}{l}14.284 \\
(14.024 \\
14.543)\end{array}$ & $\begin{array}{l}20.635 \\
(20.488 \\
20.782)\end{array}$ \\
\hline LRT $^{\mathrm{c}}, P$-value & $<0.001$ & $<0.001$ & $<0.001$ & $<0.001$ & $<0.001$ \\
\hline
\end{tabular}

Adjusted for year, age, 45-day moving daily average atmospheric pressure, sunshine duration, relative humidity and wind speed.

a Linear analysis, $P$-value $<0.05$ indicates a linear relationship.

${ }^{b}$ Non-linear analysis.

${ }^{\mathrm{c}} P<0.05$ means Model $B$ is significantly different from Model A, which indicates a non-linear relationship.

Abbreviations: $\mathrm{PM}_{2.5}$, particulate matter with an aerodynamic diameter of $\leq 2.5 \mu \mathrm{m} ; 250 \mathrm{HD}, 25$-hydroxy vitamin $\mathrm{D} ; \mathrm{Cl}$, confidence interval; LRT, logarithmic likelihood ratio test.

Table 3B. Threshold effect analysis examining associations between 60-day moving daily average $\mathrm{PM}_{10}$ level and maternal serum 250HD levels during second trimester in subgroups stratified by season of 
blood collection

\begin{tabular}{|c|c|c|c|c|c|}
\hline & Spring & Summer & Autumn & Winter & Total \\
\hline Model $A^{a}$ & & & & & $\begin{array}{l}P \text { - } \\
\text { interaction: } \\
<0.001\end{array}$ \\
\hline $\begin{array}{l}\text { One line slope, } \beta \\
(95 \% \mathrm{Cl}) P \text {-value }\end{array}$ & $\begin{array}{l}-0.102 \\
(-0.142 \\
-0.061) \\
<0.0001\end{array}$ & $\begin{array}{l}-0.058 \\
(-0.098 \\
-0.019) \\
0.0040\end{array}$ & $\begin{array}{l}-0.003 \\
(-0.062 \\
0.057) \\
0.9227\end{array}$ & $\begin{array}{l}-0.023 \\
(-0.044 \\
-0.002) \\
0.0313\end{array}$ & $\begin{array}{l}-0.039 \\
(-0.049 \\
-0.028) \\
<0.0001\end{array}$ \\
\hline Model $B^{b}$ & & & & & $\begin{array}{l}P \text { - } \\
\text { interaction: } \\
0.383\end{array}$ \\
\hline $\begin{array}{l}\text { Turning point }(\mathrm{K}) \text {, } \\
\mu \mathrm{g} / \mathrm{m}^{3}\end{array}$ & 93.15 & 45.07 & 38.10 & 113.18 & 38.28 \\
\hline $\begin{array}{l}<\mathrm{K}, \beta(95 \% \mathrm{Cl}) P- \\
\text { value }\end{array}$ & $\begin{array}{l}-0.080 \\
(-0.122 \\
-0.038) \\
0.0002\end{array}$ & $\begin{array}{l}-0.310 \\
(-0.430 \\
-0.189) \\
<0.0001\end{array}$ & $\begin{array}{l}-1.121 \\
(-1.513 \\
-0.728) \\
<0.0001\end{array}$ & $\begin{array}{l}-0.012 \\
(-0.034 \\
0.010) \\
0.2946\end{array}$ & $\begin{array}{l}-0.711 \\
(-0.841 \\
-0.580) \\
<0.0001\end{array}$ \\
\hline $\begin{array}{l}>\mathrm{K}, \beta(95 \% \mathrm{Cl}) P \text { - } \\
\text { value }\end{array}$ & $\begin{array}{l}-0.530 \\
(-0.734 \\
-0.325) \\
<0.0001\end{array}$ & $\begin{array}{l}-0.030 \\
(-0.071 \\
0.012) \\
0.1648\end{array}$ & $\begin{array}{l}-0.046 \\
(-0.108 \\
0.015) \\
0.1383\end{array}$ & $\begin{array}{l}-0.379 \\
(-0.576 \\
-0.182) \\
0.0002\end{array}$ & $\begin{array}{l}-0.038 \\
(-0.049 \\
-0.027) \\
<0.0001\end{array}$ \\
\hline $\begin{array}{c}\text { Slope } 2-\text { Slope } \\
1, \beta(95 \% \mathrm{Cl}) P \text {-value }\end{array}$ & $\begin{array}{l}-0.450 \\
(-0.661 \\
-0.239) \\
<0.0001\end{array}$ & $\begin{array}{l}0.280 \\
(0.154 \\
0.407) \\
<0.0001\end{array}$ & $\begin{array}{l}1.074 \\
(0.702 \\
1.447) \\
<0.0001\end{array}$ & $\begin{array}{l}-0.367 \\
(-0.570 \\
-0.165) \\
0.0004\end{array}$ & $\begin{array}{l}0.673(0.542, \\
0.803) \\
<0.0001\end{array}$ \\
\hline $\begin{array}{l}\text { Predicted } 250 \mathrm{HD} \\
\text { levels at } \mathrm{K}(95 \% \mathrm{Cl}) \text {, } \\
\mathrm{ng} / \mathrm{mL}\end{array}$ & $\begin{array}{l}14.927 \\
(14.625, \\
15.230)\end{array}$ & $\begin{array}{l}20.666 \\
(20.345 \\
20.988)\end{array}$ & $\begin{array}{l}20.828 \\
(20.475 \\
21.180)\end{array}$ & $\begin{array}{l}12.769 \\
(12.366 \\
13.172)\end{array}$ & $\begin{array}{l}20.950 \\
(20.789 \\
21.112)\end{array}$ \\
\hline LRT $^{\mathrm{c}}, P$-value & $<0.001$ & $<0.001$ & $<0.001$ & $<0.001$ & $<0.001$ \\
\hline
\end{tabular}

Adjusted for year, age, 60-day moving daily average atmospheric pressure, sunshine duration, relative humidity and wind speed.

aLinear analysis, $P$-value $<0.05$ indicates a linear relationship.

${ }^{b}$ Non-linear analysis.

${ }^{\mathrm{c}} P<0.05$ means Model $B$ is significantly different from Model $A$, which indicates a non-linear relationship.

Abbreviations: $\mathrm{PM}_{10}$, particulate matter with an aerodynamic diameter of $\leq 10 \mu \mathrm{m} ; 250 \mathrm{HD}, 25$-hydroxy vitamin $\mathrm{D} ; \mathrm{Cl}$, confidence interval; LRT, logarithmic likelihood ratio test. 
Table 4A. Associations between 45-day moving daily average $\mathrm{PM}_{2.5}$ levels and maternal serum $250 \mathrm{HD}$ levels during second trimester of pregnancy in subgroups stratified by meteorological factors

\begin{tabular}{|c|c|c|c|}
\hline & $\mathrm{N}$ & $\beta(95 \% \mathrm{Cl}) P$-value & $\begin{array}{l}P \text {-value for } \\
\text { interaction }\end{array}$ \\
\hline $\begin{array}{l}\text { 45-day moving daily average atmospheric } \\
\text { pressure }\end{array}$ & & & $<0.0001$ \\
\hline Tertile 1 (1002.65 - 1010.69 hPa) & 9247 & $\begin{array}{l}-0.191(-0.250,-0.132) \\
<0.0001\end{array}$ & \\
\hline Tertile 2 (1010.74 - 1020.73 hPa) & 9260 & $\begin{array}{l}-0.042(-0.077,-0.007) \\
0.0193\end{array}$ & \\
\hline Tertile 3 (1020.75 - 1028.82 hPa) & 9261 & $\begin{array}{l}-0.023(-0.041,-0.005) \\
0.0141\end{array}$ & \\
\hline $\begin{array}{l}\text { 45-day moving daily average relative } \\
\text { humidity }\end{array}$ & & & $<0.0001$ \\
\hline Tertile $1(62.58-71.11 \%)$ & 9220 & $\begin{array}{l}0.140(0.105,0.175) \\
<0.0001\end{array}$ & \\
\hline Tertile 2 (71.13 - $77.04 \%)$ & 9275 & $\begin{array}{l}-0.086(-0.111,-0.060) \\
<0.0001\end{array}$ & \\
\hline Tertile 3 (77.07 - $94.33 \%)$ & 9273 & $\begin{array}{l}-0.135(-0.169,-0.102) \\
<0.0001\end{array}$ & \\
\hline $\begin{array}{l}\text { 45-day moving daily average sunshine } \\
\text { duration }\end{array}$ & & & $<0.0001$ \\
\hline Tertile 1 (1.28 - 4.10 hours) & 9136 & $\begin{array}{l}-0.044(-0.064,-0.024) \\
<0.0001\end{array}$ & \\
\hline Tertile 2 (4.12 - 5.14 hours) & 9303 & $\begin{array}{l}-0.030(-0.063,0.003) \\
0.0717\end{array}$ & \\
\hline Tertile 3 (5.15 - 8.68 hours) & 9329 & $\begin{array}{l}-0.190(-0.242,-0.137) \\
<0.0001\end{array}$ & \\
\hline 45-day moving daily average wind speed & & & 0.2390 \\
\hline Tertile $1(1.36-1.87 \mathrm{~m} / \mathrm{s})$ & 9138 & $\begin{array}{l}-0.068(-0.088,-0.049) \\
<0.0001\end{array}$ & \\
\hline Tertile $2(1.88-2.12 \mathrm{~m} / \mathrm{s})$ & 9117 & $\begin{array}{l}-0.040(-0.069,-0.011) \\
0.0066\end{array}$ & \\
\hline Tertile 3 (2.13 - $2.65 \mathrm{~m} / \mathrm{s})$ & 9513 & $\begin{array}{l}-0.047(-0.091,-0.004) \\
0.0331\end{array}$ & \\
\hline
\end{tabular}


Adjusted for year, season, 45-day moving daily average atmospheric pressure, sunshine duration, relative humidity and wind speed except the subgroup variable.

Abbreviations: $\mathrm{PM}_{2.5}$, particulate matter with an aerodynamic diameter of $\leq 2.5 \mu \mathrm{m} ; 250 \mathrm{HD}, 25$-hydroxy vitamin $\mathrm{D} ; \mathrm{Cl}$, confidence interval.

Table 4B. Associations between 60-day moving daily average $\mathrm{PM}_{10}$ levels and maternal serum 250HD levels during second trimester of pregnancy in subgroups stratified by meteorological factors 


\begin{tabular}{|c|c|c|c|}
\hline & $\mathrm{N}$ & $\beta(95 \% \mathrm{Cl}) P$-value & $\begin{array}{l}P \text {-value for } \\
\text { interaction }\end{array}$ \\
\hline $\begin{array}{l}\text { 60-day moving daily average atmospheric } \\
\text { pressure }\end{array}$ & & & $<0.0001$ \\
\hline Tertile 1 (1003.24 - 1010.76 hPa) & 9241 & $\begin{array}{l}-0.154(-0.190,-0.118) \\
<0.0001\end{array}$ & \\
\hline Tertile 2 (1010.78 - 1020.92 hPa) & 9270 & $\begin{array}{l}-0.132(-0.157,-0.108) \\
<0.0001\end{array}$ & \\
\hline Tertile 3 (1020.97 - 1028.09 hPa) & 9257 & $\begin{array}{l}-0.021(-0.037,-0.005) \\
0.0100\end{array}$ & \\
\hline $\begin{array}{l}60 \text {-day moving daily average relative } \\
\text { humidity }\end{array}$ & & & $<0.0001$ \\
\hline Tertile 1 (63.32 - $71.30 \%)$ & 9189 & $\begin{array}{l}0.071(0.044,0.099) \\
<0.0001\end{array}$ & \\
\hline Tertile 2 (71.32 - $77.18 \%)$ & 9289 & $\begin{array}{l}-0.053(-0.071,-0.035) \\
<0.0001\end{array}$ & \\
\hline Tertile 3 (77.23 - $92.27 \%)$ & 9290 & $\begin{array}{l}-0.074(-0.096,-0.051) \\
<0.0001\end{array}$ & \\
\hline $\begin{array}{l}\text { 60-day moving daily average sunshine } \\
\text { duration }\end{array}$ & & & $<0.0001$ \\
\hline Tertile 1 (1.84 - 4.07 hours) & 9237 & $\begin{array}{l}-0.026(-0.043,-0.008) \\
0.0034\end{array}$ & \\
\hline Tertile 2 (4.08 - 5.15 hours) & 9234 & $\begin{array}{l}-0.057(-0.078,-0.035) \\
<0.0001\end{array}$ & \\
\hline Tertile 3 ( 5.16 - 7.90 hours) & 9297 & $\begin{array}{l}-0.128(-0.157,-0.099) \\
<0.0001\end{array}$ & \\
\hline 60-day moving daily average wind speed & & & 0.0032 \\
\hline Tertile $1(1.34-1.89 \mathrm{~m} / \mathrm{s})$ & 8993 & $\begin{array}{l}-0.043(-0.059,-0.027) \\
<0.0001\end{array}$ & \\
\hline Tertile $2(1.90-2.11 \mathrm{~m} / \mathrm{s})$ & 9306 & $\begin{array}{l}-0.078(-0.102,-0.054) \\
<0.0001\end{array}$ & \\
\hline Tertile $3(2.12-2.58 \mathrm{~m} / \mathrm{s})$ & 9469 & $\begin{array}{l}-0.094(-0.124,-0.065) \\
<0.0001\end{array}$ & \\
\hline
\end{tabular}

Adjusted for year, season, 60-day moving daily average atmospheric pressure, sunshine duration, relative humidity and wind speed except the subgroup variable.

Abbreviations: $\mathrm{PM}_{10}$, particulate matter with an aerodynamic diameter of $\leq 10 \mu \mathrm{m} ; 250 \mathrm{HD}, 25$-hydroxy vitamin $\mathrm{D} ; \mathrm{Cl}$, confidence interval. 


\section{Figures}

\section{Figure 1}

Temporal trends in monthly average serum $250 \mathrm{HD}$ concentration vs. monthly average $\mathrm{PM}_{2.5}$ concentration (A), $\mathrm{PM}_{10}$ concentration (B), atmospheric pressure (C), temperature (D), relative humidity $(E)$, sunshine duration (F), and wind speed (G) from January 2016 to December 2020. 250HD, 25-hydroxy vitamin $\mathrm{D} ; \mathrm{PM}_{2.5}$, particulate matter with an aerodynamic diameter of $\leq 2.5 \mu \mathrm{m} ; \mathrm{PM}_{10}$, particulate matter with an aerodynamic diameter of $\leq 10 \mu \mathrm{m}$.

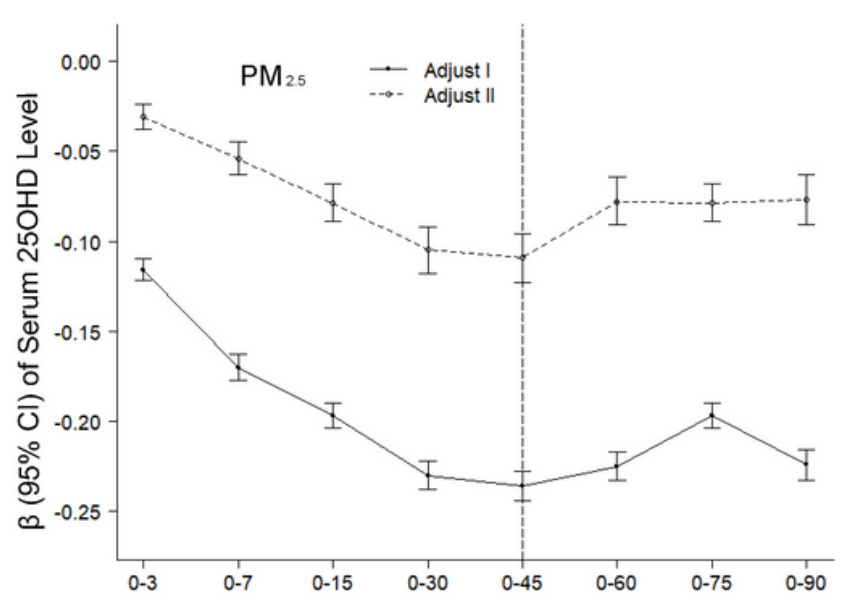

A

Lag days

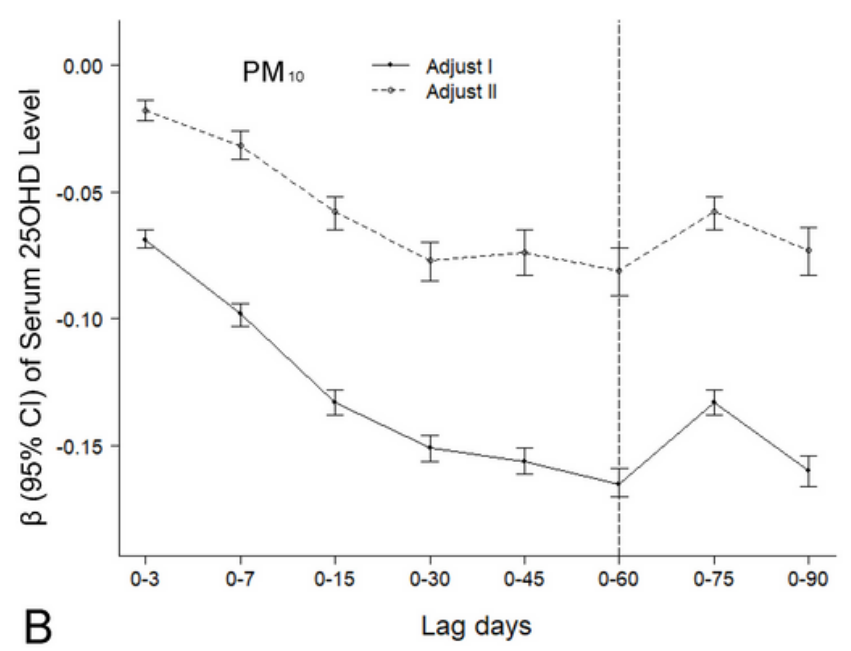

\section{Figure 2}

Association among exposure to $\mathrm{PM}_{2.5}(\mathrm{~A})$ or $\mathrm{PM}_{10}(\mathrm{~B})$ and maternal serum $250 \mathrm{HD}$ levels during pregnancy. The cumulative effects of PM were divided into four levels based on quartiles. After adjusting for year and age at blood collection (adjust I) or year, season, and age at blood collection (adjust II), the $\beta$ values $(95 \% \mathrm{Cl})$ of maternal serum $250 \mathrm{HD}$ levels during pregnancy were calculated based on the group trend. The dashed vertical line represents lag days corresponding to the maximum cumulative effects. $250 H D, 25$-hydroxy vitamin $\mathrm{D} ; \mathrm{PM}_{2.5}$, particulate matter with an aerodynamic diameter of $\leq 2.5 \mu \mathrm{m} ; \mathrm{PM}_{10}$, particulate matter with an aerodynamic diameter of $\leq 10 \mu \mathrm{m} ; \mathrm{Cl}$, confidence interval. 


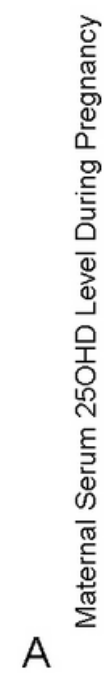

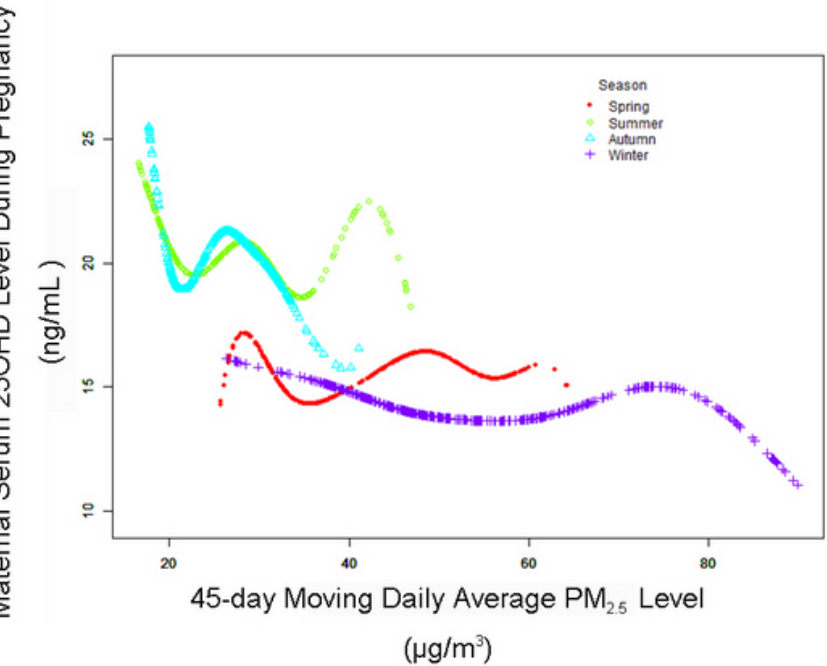

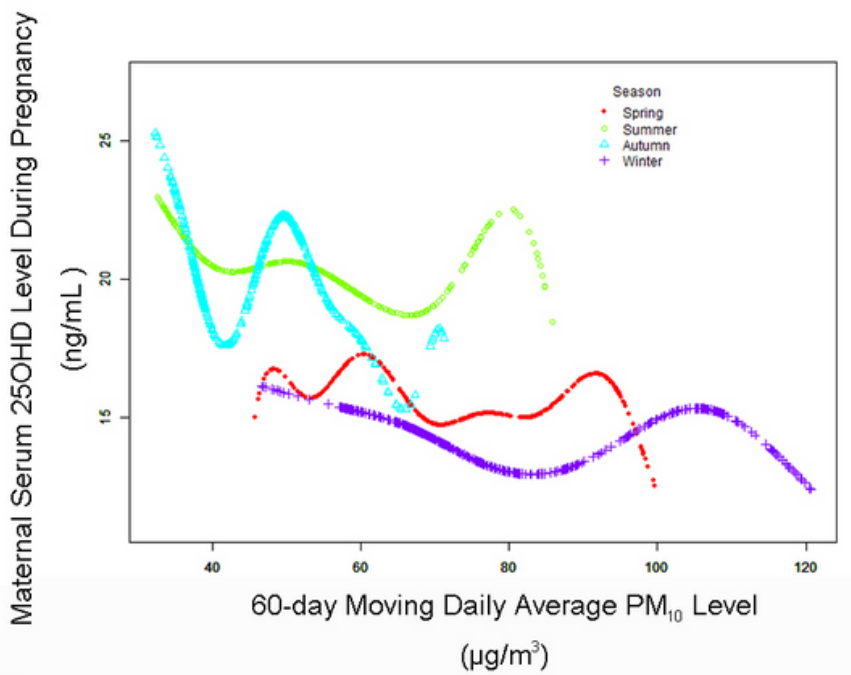

Figure 3

Adjusted smoothed curves for 45-day moving daily average $\mathrm{PM}_{2.5}$ concentration (A), 60-day moving daily average $\mathrm{PM}_{10}$ concentration (B), and maternal serum $250 \mathrm{HD}$ levels during pregnancy stratified by seasons. Thresholds were nonlinear associations between PM and 250HD, as evidenced in generalized additive models. Adjustment factors included year, age, corresponding-day moving daily average atmospheric pressure, sunshine duration, relative humidity, and wind speed. 250HD, 25-hydroxy vitamin D; $\mathrm{PM}_{2.5}$, particulate matter with an aerodynamic diameter of $\leq 2.5 \mu \mathrm{m} ; \mathrm{PM}_{10}$, particulate matter with an aerodynamic diameter of $\leq 10 \mu \mathrm{m}$.

\section{Supplementary Files}

This is a list of supplementary files associated with this preprint. Click to download.

- FigureS1.jpg

- FigureS2.jpg

- FigureS3.jpg

- FigureS3.jpg

- FigureS4.jpg

- TableS1.docx

- Tables2.docx

- TableS3.docx

- Tables4.docx

- TableS5.docx

- TableS6.docx 